\title{
Multilingualism in English language classrooms in Croatia: Can we think outside the box?
}

\author{
Mirna Trinki \\ Faculty of Humanities and Social Sciences, University of Zagreb, Croatia \\ mirna.trinki@gmail.com \\ Stela Letica Krevelj \\ Faculty of Humanities and Social Sciences, University of Zagreb, Croatia \\ sletica2@ffzg.hr
}

\section{Introduction}

In order to strengthen the social cohesion and turn the linguistic heterogeneity into an asset, the Commission of the European Communities (2008) has set the promotion of multilingualism and language learning as one of its focal tasks. Having adopted the language policy which would enable EU citizens to communicate in two additional foreign languages alongside their mother tongue (Commission of the European Communities, 2008, p. 4), multilingualism (plurilingualism) has been set as an educational goal in the school systems of EU countries (European Commission 2017). Additionally, in the last 20 years, research on the educational aspect of multilingualism has intensified, encouraged by more or less empirically validated claims on the benefits of multilingualism and multiple language learning.

At the same time, multilingualism in classrooms in the EU is becoming a norm. This is due to the fact that learners, besides majority language, also speak various regional languages, foreign languages, or migrant languages. As a result, in recent years, there has been an increase in the number of proposals of pluralistic approaches to languages and cultures and integrated language learning curricula which acknowledge learners' previous linguistic knowledge (their linguistic repertoires).

However, the linguistic situation is not the same in all member countries. While the EU as a whole is faced with a growing level of multilingualism, both at a societal and individual level, the linguistic situation in Croatia is quite homogenous; with the vast majority of learners in Croatian classrooms being native speakers of the dominant language, Croatian. Although Croatia has a long history of foreign language learning, and its speakers are often proficient speakers of at least one foreign language, multilingualism at the 
individual level is almost exclusively the result of learning foreign languages in an additive manner as separate school subjects. Same as in many countries of the EU, English is most commonly the first foreign language learned at school, and there are voiced concerns that the hegemony of English may stand in the way of the promotion of multilingualism and additional language learning.

When trying to strike a balance between available research and language policy recommendations at the EU level, and the implementation of such policies at the level of member countries, it is necessary to look at numerous factors both directly and indirectly related to the socio-educational context in which it takes place. The implementation of educational policies depends inter alia on teachers' attitudes and beliefs as they underlie the choices teachers make in the classroom and the extent to which they accept new teaching approaches and strategies (Borg, 2003).

In the light of the proposals that argue for approaches to teaching which soften the boundaries between languages (e.g., Cenoz \& Gorter, 2015), we looked into the beliefs of English language teachers in Croatia whose classrooms are predominantly populated by learners with the same L1- Croatian. As many teachers may be multilingual, we were interested in their awareness of the potential it may have in their teaching practice and their attitudes to introducing other languages into their English language classrooms.

\section{Theoretical background}

\subsection{From monolingual ideology to the multilingual turn}

Language education has traditionally been guided by the ideology of language separation which, as put forward by Cummins (2007, p. 221), is characterized by the following beliefs: keeping languages separated, exclusive use of the target language, and no translation between the target language and the L1. The idea of language separation dates back from the Direct Method of language teaching (Cenoz \& Gorter, 2015; Cummins, 2007) based on the premise that the contact between languages could provoke confusion and prevent learners form internalizing a new language.

This is often referred to as the monolingual ideology (Cenoz \& Gorter, 2014, 2015), fixed multilingualism (Horner \& Weber, 2017), parallel monolingualism or separate bilingualism (Creese \& Blackledge, 2010), and it is still found in educational context around the world amongst teachers who maintain that the target language should be isolated (Cenoz \& Gorter, 2014, p. 240). Indicative of such perception is the usual target-language-only classroom practice and independent language syllabus, which unfortunately is often found even in schools aiming towards multilingualism (Cenoz \& Gorter, 2011). This ideology has provoked some educational issues over the years, especially in today's context of growing multilingualism. An additional fact pointing to its inadequacy is Cummins's (2007) theory of 
interrelation between languages, according to which the skills and abilities that students acquire in their L1 or L2 are not confined, but can easily be passed on across all the languages in their linguistic repertoires.

Following the interrelation theory (Cummins, 2007), a need for reassessing the monolingual ideology arose (Creese \& Blackledge, 2010, p. 105), and it resulted in holistic views of language teaching and a call for softening the boundaries between languages (Cenoz \& Gorter, 2013, Cummins, 2017). Foreign language teaching approaches taken in different countries around Europe range from the traditional additive one, where languages are taught as separated school subjects promoting the target-language-only policy, to a fully curricular or integrated approach which aims to form strong links between languages taught at school.

Focus on Multilingualism (Cenoz \& Gorter 2011, 2015) focuses on the speaker's whole linguistic repertoire and aims at establishing connections between languages by using translanguaging pedagogical practices (see García, 2009; García \& Wei, 2014), and enhancing metalinguistic awareness (Cenoz \& Gorter, 2011). The main goal behind such educational approaches is the need to soften the boundaries between languages and integrate the language curricula in order for learners to benefit from their prior linguistic knowledge, metalinguistic awareness and all the other skills they possess as multilingual speakers (Cenoz \& Gorter, 2011, 2014). Similar idea was put forward by Hélot (2008) advocating Language Awareness (LA) as an educational approach which, unlike the traditional foreign language learning, focuses on "adopting a comparative approach of linguistic systems" (Hélot, 2008, p. 4).

There are different conceptions of multilingual education and its implementation is achieved with different focal aims and objectives. This can range from catering for the needs of learners of additional languages to the teaching of more languages in an integrated way (see Lionet, Cenoz \& Gorter, 2017). Some of the educational projects and approaches promoting plurilingualism and pluriculturalism are the tertiary language learning (Hufeisen \& Neuner, 2004), the framework for plurilingual descriptors and classroom activities (Candelier et al., 2012) and more recently the projects such as the PlurCur project (plurilingual whole school policy), aiming at the inclusion of more languages across all subjects (Allgäuer-Hackl, Brogan, Henning, Hufeisen \& Schlabach, 2018).

Additionally, research on third language acquisition has shown that learners rely on previously acquired languages in building knowledge of an additional language (Ringbom, 2007), and that multilingual teaching approaches can promote additional language learning and generate more beneficial effects than those achieved in monolingual language classes (Cenoz, 2003; Jessner, 2008). Furthermore, it is claimed that learning multiple languages is conducive to a specific multilingual proficiency (Herdina \& Jessner, 2002) or "holistic multicompetence" (Cook 1992: 566) which contributes to the language learning process. 
Accepting the fact that under favourable conditions multilingualism is a benefit for cognitive development, and that it carries a potential for enhancing other affective and social benefits for functioning in the multilingual world, the main question revolves around the best and contextually most appropriate way to incorporate the idea of multilingualism as a principle of language education. Some of the ways of introducing multilingualism into FL classrooms are:

- $\quad$ comparison of languages - comparing and contrasting structures, vocabulary, and concepts across the languages in students' repertoires (Jessner, 2006; Jessner, et al., 2016).

- $\quad$ introducing dual-language and multilingual books (Hélot, 2011).

- $\quad$ intercomprehension as a pedagogical approach (Doyé, 2005).

- $\quad$ linguistic landscapes - used as a pedagogical tool (Gorter, 2006).

- $\quad$ pedagogical translanguaging (García, 2009; García \& Li Wei, 2015; Leonet, Cenoz \& Gorter, 2017).

Of greatest interest to this study is language awareness that can be fostered in the foreign language classroom. Due to the elusiveness and different understandings of the construct, this is still a largely underexplored research topic. However, research findings mostly suggest its positive benefits, such as learners' greater ability to deal with complex linguistic features and the promotion of learners' noticing of forms and features of a foreign language (for a detailed review see Sierens, Frijns, Van Gorp, Sercu \& Van Avermaet, 2018). Based on the review of research on LA between 1995 and 2013, Sierens et al. (2018) concluded that LA approach has some effect on learners' affective and social development in the form of positive attitudes towards linguistic diversity, and more favourable perceptions of different languages and of speakers of these languages. They were more careful about its effect on cognitive skills and metalinguistic sensitivity suggesting that prolonged and more intensive focus of LA is necessary for the results to be obtained.

Further efforts were made in terms of providing concrete activities for fostering multilingual awareness (for the construct see Jessner, 2006) in multilingual learners. Jessner, Allgäuer-Hackl and Hofer (2016) provided empirical evidence that multilingual activities, which build on the language synergies and previous linguistic knowledge and learning experience, can make the learning of the target language, as well as other languages in students' repertoire, more efficient.

Nevertheless, the studies, which resulted in these educational proposals, have been conducted mostly in bilingual/multilingual socio-educational contexts. Relatively little attention has been given to the predominantly monolingual contexts where teachers and learners share the same L1 and multilingualism is achieved in an additive manner through languages being taught separately in formal settings. We agree with García (2014) that the context in with each language is an island on its own, is not truly conducive to multilingualism. If we assume that the promotion of multilingualism can have specific 
affective, cognitive, and social goals, the question that follows is to what extent it can be fostered through the above identified multilingual approaches in different socio-educational contexts.

\subsection{Teachers' beliefs and attitudes towards multilingualism and multilingual practices in the classroom}

Teacher's beliefs and thoughts are an important aspect to the teaching process (Borg, 2003, p. 81). As Borg (2003) explains, "teachers are active, thinking decision-makers who make instructional choices by drawing on complex, practically-oriented, personalised, and context-sensitive networks of knowledge, thoughts, and beliefs" (p. 81). In other words, as summarized by Borg (2006), teacher cognition, teaching context, and teacher experience (both professional and personal) interact with each other in the process of language learning. Thus, understanding this cognitive dimension of teaching can help us understand the decisions teachers make in the classroom (Haukås, 2016, p. 12; Egaña, Cenoz \& Gorter, 2015, p. 169; Cybulska \& Kabalin Borenić, 2014, p. 75, 77; De Angelis, 2011, p. 217). Apart from the experience they had as language learners, teachers' beliefs on multilingualism may also be shaped by "the relative status of the languages in society and the institutional decisions about the curriculum, including the textbooks and materials used" (Egaña, Cenoz \& Gorter, 2015, p. 172). Despite the fact that teachers play the pivotal role in promoting multilingualism and the use of prior linguistic knowledge (Haukås, 2016, p.1-2), research on teachers' beliefs and attitudes towards multilingualism and especially multilingual pedagogical practices was surprisingly scarce until recently and it focused largely on migrant and minority language contexts. De Angelis (2011) reported on the beliefs of Italian, Austrian and UK teachers about the role of prior language knowledge and their impact on teaching practices. Her study showed that, despite their beliefs being positive, most teachers still thought languages should be kept apart and treated as separate. The teachers avoided making references to students' home language and culture and did not allow their use in the classroom. Egaña, Cenoz and Gorter (2015) also found that primary school teachers in the Basque Country and Friesland were reluctant to allow their students to code-switch, insisting on the use of a target language, although almost all the teachers admitted they often spontaneously used code-switching in their classrooms and some (teachers in Friesland) even used it as a teaching strategy. With the exception of a few teachers who believed language teaching should be interconnected, the authors concluded that the monolingual ideology still prevailed.

Portolés and Martí (2018) examined the beliefs of pre-service subject teachers in Valencia, Spain, on teaching English as an L3. They compared teachers' beliefs before and after a training course on the multilingual teaching approach. The teachers' initial support towards the monolingual ideology was attributed to individual linguistic background and the 
lack of multilingualism training programmes, but Portolés and Martí (2018) concluded that teachers' beliefs were susceptible to training and stressed the crucial role training had in reshaping perceptions (p. 4). The problem of insufficient teacher training was also recorded in studies that included language teachers. In Griva and Chostelidou (2012), foreign language teachers in Greece highlighted the importance of in-service teaching, expressing the need for reorganizing teaching approaches in order to address multilingualism requirements. However, it should also be noted that, although having positive attitudes towards multilingualism and its promotion, only a few teachers (1.9\%) mentioned cooperation between foreign language teachers and L1 teachers (Griva \& Chostelidou, 2012, p. 265).

Apart from general attitudes towards multilingualism, it is important to understand language teachers' beliefs and practices when it comes to multilingual and language awareness pedagogy, as these are the main tools for softening the boundaries between languages. In her study on third language teachers' beliefs about multilingualism and multilingual pedagogy in Norway, Haukås (2016) found that although all the teachers in the study said they frequently used their students' prior linguistic knowledge, this was restricted only to languages learned at school. Unfortunately, their awareness raising practices were not supported by textbook activities which called for little or almost no use of students' L1 and L2. Furthermore, even though the teachers liked the idea of collaborating with teachers of other languages, the study reported that such collaboration did not exist, mostly due to time constrains. Heyder and Schädlich (2014) also reported that FL teachers in Lower Saxony had positive attitudes to multilingual pedagogy and materials promoting multilingualism, and made a frequent (spontaneous) use of language comparison. However, the teachers rarely used multilingual materials and were somewhat reluctant to bring other languages into their classrooms if they were not familiar with them.

Positive attitudes were also found by Cybulska and Kabalin Borenić (2014) among pre-service and in-service English teachers in Croatia and Poland. When asked which activities they would use to promote pluralistic approaches, the teachers opted for analysing cross-cultural encounters, as well as scanning non-English discourses for familiar elements and structural similarities (p. 89). Additionally, they found that there was no correlation between teachers' attitudes and the number of languages they spoke or their teaching experience. These findings are particularly interesting considering the fact that both Poland and Croatia are linguistically homogenous and had not yet been affected by migrating cultures, and their foreign language teachers rarely, if ever, came into contact with students whose L1 was not Polish or Croatian. Another study in Polish context (Otwinowska 2014) examined the factors affecting teachers' levels of plurilingual awareness as well as their views on cross-linguistic practices, and corroborated the majority of the aforementioned findings. Polish teachers displayed positive attitudes towards cross-linguistic comparisons as well as the use of prior linguistic knowledge. Otwinowska (2014) found that teachers' level of plurilingual awareness did not depend solely on experience, but also on their 
linguistic background. Teachers who were multilingual and whose knowledge of L3 was somewhere at the intermediate level demonstrated higher levels of plurilingual awareness. However, they were still not prepared and confident enough to put their beliefs into practice, which was attributed to their lack of training on plurilingual education.

In sum, the majority of aforementioned studies have stressed the following: a) material promoting cross-linguistic awareness needs to be included in language textbooks in order to support multilingual classroom activities and promote the learning of multiple languages, b) coordination and cooperation need to be developed between teachers of different languages, c) teachers need to be better trained in and educated on multilingualism and multilingual pedagogies and practices.

\section{Study}

\subsection{Socio-educational background}

Even though the status of the English language has been rapidly turning from a foreign language to lingua franca or second language in most countries of the EU, the way it is taught in Croatia still preserves many features of a school subject taught in a traditional way as a "foreign language" (Letica Krevelj, 2019). While elsewhere in Europe the learner make-up in the classroom is also becoming rather heterogeneous, from the linguistic perspective, the one in Croatia is still predominantly monolingual. The official language of schooling is in the majority language, Croatian, and the learners are rarely non-native speakers of the majority language. Consequently, the question of the inclusion of other students' languages is rarely raised. The presence of different languages in the repertoire of Croatian learners is not due to the diversity of cultural and linguistic background, but the fact that learning of foreign languages is promoted through the Croatian education system.

Croatia has had a long history of teaching languages through formal education (Vilke, [1999] 2019), and the attitudes to FL learning, as well as early FL learning, have been extremely positive (Letica Krevelj, 2019). The first foreign language is introduced in the first grade of primary school (at the age of six) and the second foreign language is usually introduced in the fourth grade (at the age of ten). By the end of the secondary education (at the age of 18) the majority of learners will have studied at least two foreign languages (in addition to Latin in grammar schools).

According to the statistical data (Croatian Bureau of Statistics, 2017), 89.7\% of learners study English as the first foreign language. The second most popular language is German, followed by Italian and French. The second foreign language in primary school is taken up by approximately $62 \%$ of learners and the great majority chooses German as their second foreign language. 
FL syllabus is still mostly based on the communicative approach to teaching and the ideal of exclusive target language use. At the same time, the teaching is still largely based on formal syllabus which puts a lot of emphasis on explicit grammar learning. Even though the Croatian education system has adopted the EU recommendations and policies regarding the promotion of multilingualism, and multilingualism is the declared aim, the additive approach to different FLs in the curriculum is the dominant one. Many discrepancies, at the language policy level, between the proposed curriculum framework and particular foreign language curriculum have already been identified (Petravić, 2015). Parents' attitudes to multilingualism and multiple language learning have been very positive (see Letica Krevelj, 2019), but little is still known about classroom practices with regard to the adoption of the multilingual approach.

\subsection{Aim of the study}

While the existing research on multilingual education draws primarily from the imminent need to cater for multilingual reality of classrooms worldwide (e.g., Hélot \& 0'Laoire, 2011), the purpose of this study was to examine the opportunities for the introduction of the multilingual approach in L1 homogeneous target-language-only FL classrooms. In other words, we investigated the possibilities for the facilitation of the multilingual perspective which may seem, at the moment and place, a divergent perspective on what has been called a tradition and common practice in FL classrooms in Croatia.

This study aimed to examine English language teachers' beliefs and attitudes towards bringing other languages into the English language classroom. More specifically, we wished to answer the following questions:

1) How receptive are the teachers to activities and materials promoting multilingualism?

2) Which benefits of the approach can they identify?

3) To what extent do they grasp the principle of the multilingual approach?

\subsection{Participants}

The participants in the study were 30 Croatian primary school teachers of English who teach children from age six to 14. Twenty-five teachers taught in state-owned primary schools, while five taught in private language schools. The teachers had an average of 20.1 years of teaching experience and only two teachers were male (6.7\%). Their native language was Croatian, and besides English, they reported speaking other languages at least at the A1 level, most commonly German and Italian (see Table 1). 
Table 1. Teachers' linguistic repertoires

\begin{tabular}{|c|c|c|}
\hline $\begin{array}{c}\text { Foreign language } \\
\text { spoken }\end{array}$ & $\begin{array}{c}\text { Number and percentage of } \\
\text { speakers }\end{array}$ & $\begin{array}{c}\text { Self-assessed } \\
\text { proficiency level }\end{array}$ \\
\hline English & $100 \%(\mathrm{~N}=30)$ & $\mathrm{C} 1-\mathrm{C} 2$ \\
\hline German & $43.34 \%(\mathrm{~N}=13)$ & $\mathrm{A} 1-\mathrm{C} 2$ \\
\hline Italian & $40 \%(\mathrm{~N}=12)$ & $\mathrm{A} 1-\mathrm{C} 2$ \\
\hline Spanish & $13.34 \%(\mathrm{~N}=4)$ & $\mathrm{A} 1-\mathrm{C} 1$ \\
\hline Portuguese & $6.67 \%(\mathrm{~N}=2)$ & $\mathrm{A} 1-\mathrm{A} 2$ \\
\hline French & $3.34 \%(\mathrm{~N}=1)$ & $\mathrm{B} 2$ \\
\hline Czech & $3.34 \%(\mathrm{~N}=1)$ & $\mathrm{B} 1$ \\
\hline Swedish & $3.34 \%(\mathrm{~N}=1)$ & $\mathrm{A} 1$ \\
\hline
\end{tabular}

\subsection{Instruments and procedure}

The participants were presented with a didactic material which could be used as a tool for promoting the multilingual approach in FL classrooms. The multilingual material was a multilingual picture book Subway Sparrow (Torres, 2012) written in three languages: English, Spanish and Polish. It features a charming story about four people (an Englishspeaking boy and a girl, a Spanish-speaking man, and a Polish-speaking woman) who are working together to save a sparrow caught in a subway car despite the fact that they each speak a different language. This simple story is an excellent example of linguistic diversity not being an obstacle, but a bridge connecting people of different cultures and backgrounds. An audio version of the book was recorded with proficient speakers of the three languages, and a short movie was made with pages from the picture book to accompany the audio for easier comprehension. ${ }^{1}$

The video was played to the teachers once (with the written text in the original languages), and afterwards they were presented with a short task which could be used as a post-listening activity with learners. The task itself involved reflecting upon the languages and lexical items encountered in the picture book and it consisted of a list of ten words from the three languages. The task required the recognition of the language to which each word belonged, the translation of each word, and additional questions aimed at raising learners' cross-linguistic and metacognitive awareness. The teachers were asked to assess the grade / proficiency level of potential learners best suited for the task. 
The teachers were then asked to fill in a questionnaire. The first part included questions regarding teachers' linguistic background and teaching experience. The second part of the questionnaire consisted of open-ended questions which elicited data on the use of language(s) in teachers' own classrooms, and their perception of the multilingual material i.e. its educational potential. The questions were formed as follows:

1. Do you usually use other languages besides English in your classroom?

a. If yes, which ones (Croatian or any other)?

b. If no, why not?

2. Do you allow your students to use any other language apart from English in the classroom? Why/why not?

3. Did you like the activity? Why/why not?

4. Do you think this material has any educational value? If yes, what is it?

5. If similar material were available to you, would you use it (multilingual picture books) in your classroom? Why/why not?

The study was conducted in the fall of 2017, on three different occasions during teachers' meetings. All the participants were informed of the aims of the study and their participation was entirely voluntary.

\section{Results and discussion}

\subsection{The use of other languages in an English language class}

All the teachers $(100 \%)$ reported using languages other than English in their English language classes. However, the language used along English was almost always Croatian, students' and teachers' L1. Most of the explanations for their use of L1 in the classroom suggested the function of facilitating and checking comprehension, but not for making connections between languages. This may be either because Croatian is typologically more distant from English than other commonly studied languages, or that it is simply felt as different due to its L1 status.

Even though the teachers themselves spoke more than one foreign language, only seven of them (23\%) reported having introduced other languages in their classrooms. Four teachers mentioned German in order to make comparisons with English (T08: I compare English and German grammar; T21: Because of similarities, pupils are glad when they see they know something) and three teachers mentioned Italian, Latin, Greek or French in order to point out the similarities between Indo-European languages or word etymology (T10: To explain that some words are similar in other languages or to point out their origin). It is possible, however, that the teachers were reluctant to report such practices as these were neither promoted during their pre- or in-service education, nor clearly articulated in the FL curriculum. 
The situation was similar on the question of allowing students the use of other languages during English classes. Almost all teachers $(\mathrm{N}=29,97 \%)$ allowed the use of Croatian for comprehension purposes, translation or because the students were unable to express themselves in English. Even though only one teacher answered negatively, there were four teachers who suggested that the use of Croatian was allowed only to the youngest / least proficient learners (T02: Only at the beginning, before we become more skilled in the classroom language). It is important to emphasize that, when explaining the use of Croatian in their classrooms, most teachers felt a need to provide an excuse for doing so (T11: Just to make sure there is no misunderstanding, other than that, the use of L1 in minimal). Only six teachers justified the use of other languages by explaining the benefits they believed it had for their learners (T15: The use of other languages can be more motivating, it can create a more positive atmosphere and lead to better learning outcomes).

\subsection{Teacher reactions to the multilingual picture book}

All the teachers reacted positively to the multilingual picture book and the task. However, 19 teachers (60\%) liked the picture book for reasons not related to the multilingual aspect. The reasons they provided referred to the fact that it was an authentic, audio-visual material, or that it could be exploited as a didactic material for teaching the target language. Only 11 teachers $(36.7 \%)$ provided reasons related to the presence of the three languages in the story book. The potential of raising awareness of multilingualism and multiculturalism was mentioned as a reason by $26 \%$ of teachers $(\mathrm{N}=8)$, whereby they either simply stated that it was in line with the EU policies, or they mentioned its specific goals such as raising awareness of different languages and cultures of the EU, or promoting intercomprehension. (T18: Pupils will see that they do not have to be proficient in a language to communicate with others; T04: It fits well with the trend of multilingual development; T27: It may motivate learners to learn other languages).

Only three teachers $(10 \%)$ liked the material because they recognized its potential for promoting cross-linguistic awareness. The three teachers mentioned the usefulness of drawing comparisons between different languages and raising students' awareness of similarities and differences between them. One of the three teachers also suggested that the picture book should contain languages students were already learning (T30: It would be ideal if the combination were English-German, because these are the languages students learn at school so the benefit would be twofold). The emphasis seems to be placed on the benefit the activity may have on the proficiency in languages students were learning as in "killing two birds with one stone", rather than raising cross-linguistic awareness. The teachers' reactions might have been different if the story were written in languages students were learning at school - Croatian, English and German. We may wonder whether the teachers would have liked it more or less, or recognized more benefits of such material if this were the case. 


\subsection{The educational potential of the picture book}

All the teachers readily provided more than a single answer to the question of the educational potential of the picture book. The question asked was rather general in order to see what the teachers themselves would list as most important. The answers were divided in two categories: educational values related and those not related to multilingualism.

The teachers frequently identified the potential of promoting moral values and team work. This was not surprizing as this was one of the main issues of the original picture book which promoted the idea that a goal can be accomplished even when people did not speak each other's languages. Thus, somewhat surprizing may be the fact that six teachers mentioned the importance of learning languages as the most important educational value of the picture book. We believe that it simply reflects the importance of learning foreign languages that is very much ingrained in the Croatian society. A few teachers also identified particular aspects of the target language(s) that could be taught using the picture book (see Table 2).

Table 2. Identified educational potential not related to multilingualism

\begin{tabular}{|c|c|}
\hline Educational potential & No. of answers \\
\hline Social /moral values, cooperation and team work & 12 \\
\hline Importance of learning other languages & 6 \\
\hline Learning two languages simultaneously & 3 \\
\hline Teaching elements of the target language & 2 \\
\hline Total & 23 \\
\hline
\end{tabular}

When it comes to the educational potential related to multilingualism, the teachers most commonly referred to affective aspects such as general awareness of multilingualism in the world and promotion of tolerance among people speaking different languages. The promotion of cross-linguistic awareness was mentioned only in three instances, and only one teacher referred to the potential of promoting learners' use of other languages in the classroom (Table 3).

Table 3. Identified educational potential related to multilingualism

\begin{tabular}{|c|c|c|}
\hline $\begin{array}{c}\text { Aspects of } \\
\text { multilingualism }\end{array}$ & Educational potential & No. of answers \\
\hline \multirow{2}{*}{ Affective } & Awareness of multilingualism and tolerance & 15 \\
\cline { 2 - 3 } & Motivation for learning additional languages & 1 \\
\hline Cognitive & Cross-linguistic awareness & 3 \\
\hline Socio-interactional & $\begin{array}{c}\text { Promoting learners' use of different } \\
\text { languages in the classroom }\end{array}$ & 1 \\
\hline & Total & 20 \\
\hline
\end{tabular}




\subsection{Including the multilingual picture book in the English language classroom}

The next question inquired into teachers' willingness to include a multilingual material in their classroom. We were particularly interested in answers of those teachers who referred to the multilingual aspect of the picture book as we wanted to gauge the extent to which they see this aspect integrated into their own English classrooms.

To our delight, all the teachers stated that they would use such material were it available to them, which is a good argument in favour of developing similar material in the future. However, based on the teachers' explanations of the aims for which they would use the material, we found that $63 \%$ of teachers actually targeted the development of the English language proficiency. The reasons they provided were simply related to the novelty effect such material would have in the teaching practice, suggesting that it would be more motivating for students or that it could be used for the teaching of learning strategies. Many teachers actually pointed out that the topic was in line with the thematic aims of the English language curriculum and that they would use it for teaching vocabulary and grammatical features of the English language.

Eleven teachers (37\%) stated that they would use the material in their class for the reasons related to the multilingual aspect. Three of them stated rather vaguely that it would promote the awareness of multilingualism and multiculturalism in the EU. Seven of them mentioned the aim of promoting language awareness and cross-linguistic awareness (T01: Thinking about language in general, not just English; interlanguage transfer). Again, one of the teachers pointed out the aforementioned importance of the language combination, explaining that "[i]f the material were in languages the students are learning, [students] could compare sentences, construction and words" (T30).

It is important to emphasize that two out of these seven teachers stated that they would use this material in extracurricular classes. They stated explicitly that the aim of the English language subject is to "work" on the English language proficiency. Therefore, the majority stayed firmly within the borders of the English language explaining that their primary goal was to teach children to communicate in English. We believe that this clearly suggests that teachers in English language classrooms still follow the one-classroom-onelanguage ideology and that there is a long way to go before we succeed in softening the boundaries between languages.

Only one teacher who had minority students in her class suggested the aim in line with the socio-cultural dimension of multilingualism. She felt that it could promote inclusion and equality saying that "if it were in their mother tongue, they could take part and stand out" (T07). Even though it was a single case, we hope that this may suggest that the linguistic heterogeneity in the classroom can have an impact on teachers' perception of the usefulness of the multilingual approach in the educational system. 


\section{Conclusion}

The study presented in this paper constitutes a small step towards striking a balance between the predominantly monolingual environment in which FL learning takes place and the recommendations of European Commission and research on multilingualism on purported benefits of multilingualism and multiple language learning. We set to examine how receptive Croatian teachers were to materials promoting multilingualism, which benefits of the materials they could identify, and the extent to which they accepted the promotion of multilingualism as an educational goal through language teaching.

Having presented the teachers with the example of a multilingual didactic material, we concluded that the teachers were positive about the material, but their focus was mainly on non-linguistic aspects of multilingualism. Despite their overall liking of the picture book, the teachers did not entertain the idea that it could contribute to overall linguistic competence. Only around $30 \%$ of teachers showed inclination towards promoting learners' metalinguistic and cross-linguistic awareness, but even they often pointed out some contextual factors as obstacles on their path of practicing the multilingual approach (e.g. public exams and curricular constraints). It is in all fairness that we should state that this perspective may have been truly adopted only at a superficial level. This seems to be true even in multilingual socio-educational contexts (see e.g. Leonet et al., 2017), let alone in the linguistically homogeneous context such as ours.

Learning languages has been long recognized as an asset in Croatia and the implementation of the EU policies has brought nothing new in that respect. However, the EU policy documents stress not only the learning of a particular language, but also each FL classroom contributing to learners' multilingualism. Seemingly this aspect did not receive equal attention. As previously mentioned (Petravić, 2015), the teaching of English in Croatia is still focused on achieving the communicative competence in the target language, so the integration of languages in the curriculum and softening the boundaries between languages is not part of teachers' ideology.

The fact that the teachers did not appropriate the idea of the multilingual approach is not surprizing for two reasons. The teachers in the study had not been educated on multilingualism and multilingual approach during their pre- or in-service training, and multilingualism promoted through the EU policies did not follow through to the foreign language syllabi in the form of clearly articulated outcomes.

The multilingual approach contradicts the traditional foundation of foreign language teaching, e.g. ideal native speaker, in many ways (see Cenoz, 2019). Based on the analysis of our data, we could agree that multilingual approach is in conflict with the current paradigm of English language teaching in Croatia. In practical terms, in school systems which are focused on the assessment, linguistic and metalinguistic awareness as an outcome of a FL course needs to be clearly articulated and its effect / value should be obvious. There are not many empirical studies which testify to the efficacy of cross-linguistic approach when it 
comes to target language learning, and the constructs such as multilingual proficiency (Herdina \& Jessner, 2002) and holistic multicompetence (Cook, 1992) are still far removed from the actual teaching practices. We believe that this may be particularly the case with teachers of English, as English is most commonly the first foreign language, and that the teachers of languages other than English may be more susceptible to arguments for the multilingual approach.

The willingness of a single teacher with minority language speakers in her class to engage with multilingualism in the classroom was the closest to the translanguaging pedagogy we could identify in our study. We would like to suggest that translanguaging as a resource may arise when there is a true communicative need, rather than from the purported benefits of a single approach or even less so, from the language policy recommendations. In our context, it was spontaneously evoked when students with linguistically diverse backgrounds could not meet the traditional target-language-only policy.

\section{Implications of the study}

It is often the teachers who decide on the extent of the implementation of particular language policies and recommendations, and it is the ideologies and beliefs that they draw from when making decisions in the classrooms. For this reason, we believe that our study may be rather informative for similar contexts with still traditional outlook and the one-classroom-onelanguage approaches to FL teaching. These beliefs most certainly deserve further study.

We can only agree with previously identified need for teacher training on multilingual education. Teachers should be provided with available empirically tested findings and knowledge on multiple language learning so that they could reflect on their own practices in the light of these facts and recommendations. However, this may be a difficult endeavour in a case such as ours where the true reconstruction of ideologies may only be possible at the moment the realities of multilingual classrooms (linguistic diversity as opposed to monolingual and monocultural make-up) make teachers question the effectiveness, or at least the appropriateness, of current practices. The one-language-per-classroom approach seems to be deeply rooted in past ideologies which are simply perpetuated without critical reflection.

As the teachers themselves are often speakers of other languages besides English, there are many ways in which they could capitalize on that knowledge, and only the awareness of that potential may be a step away from one-language-per-classroom approach. We believe that if informed about the available knowledge (but also its limits) on the benefits of multilingualism and the multilingual approach to teaching, teachers would be capable of striking the balance between the recommendations and the realities of their own classrooms. 


\section{References}

Allgäuer-Hackl, E., Brogan, K., Henning, U., Hufeisen, B., \& Schlabach, J. (2018). More languages? - PlurCur! Research and practice regarding plurilingual whole school curricula. Strasbourg: Council of Europe Publishing.

Borg, S. (2003). Teacher cognition in language teaching: A review of research on what language teachers think, know, believe, and do. Language teaching, 36(2), 81-109.

Borg, S. (2006). Teacher cognition and language education: Research and practice. London: Continuum.

Candelier, M., Camilleri, A., \& Molinié, M. (2012). FREPA: A framework of reference for pluralistic approaches to languages and cultures: Competences and resources. Strasbourg: Council of Europe.

Cenoz, J. (2003). The additive effect of bilingualism on third language acquisition: A review. International Journal of Bilingualism, 7(1), 71-87.

Cenoz, J. (2019). Translanguaging pedagogies and English as a lingua franca. Language Teaching, 52(1), 71-85.

Cenoz, J., \& Gorter, D. (2011). Focus on multilingualism: A study of trilingual writing. The Modern Language Journal, 95(3), 356-369.

Cenoz, J., \& Gorter, D. (2013). Towards a plurilingual approach in English language teaching: Softening the boundaries between languages. TESOL Quarterly, 47(3), 591-599.

Cenoz, J., \& Gorter, D. (2014). Focus on multilingualism as an approach in educational contexts. In A. Creese \& A. Blackledge (Eds.), Heteroglossia as practice and pedagogy (pp. 239-254). Berlin: Springer.

Cenoz, J., \& Gorter, D. (2015). Towards a holistic approach in the study of multilingual education. Multilingual education: Between language learning and translanguaging, 115.

Commission of the European Communities (2008). Communication from the commission to the European Parliament, the council, the European economic and social committee and the committee of the regions. Multilingualism: an asset for Europe and a shared commitment. Retrieved November 4, 2018 from https://eur-lex.europa.eu/legalcontent/EN/TXT/HTML/?uri=LEGISSUM:ef0003\&from=EN

Cook, V. (1992). Evidence for Multicompetence. Language Learning 42, 4, 557-591.

Creese, A., \& Blackledge, A. (2010). Translanguaging in the bilingual classroom: A pedagogy for learning and teaching? The modern language journal, 94(1), 103-115.

Cummins, J. (2007). Rethinking monolingual instructional strategies in multilingual classrooms. Canadian Journal of Applied Linguistics (CJAL), 10 (2), 221-240.

Cummins, J. (2017). Teaching for transfer in multilingual school contexts. In O. García, A. Lin \& S. May (Eds.), Bilingual education. Encyclopedia of language and education. Berlin: Springer, 103-115. 
Cybulska, K., \& Kabalin Borenić, V. (2014). EFL teacher trainees and European goals of multilingualism and plurilingualism. A survey of attitudes in Poland and Croatia. In A. Otwinowska, G. De Angelis (Eds.), Teaching and Learning in Multilingual Contexts. Bristol, UK: Multilingual Matters.

Croatian Bureau of Statistics (2017). Pupils in basic schools learning foreign languages, by grades, and teachers teaching foreign languages, end of 2015/2016 school year. Statistical reports 1597/2017.

De Angelis, G. (2011). Teachers' beliefs about the role of prior language knowledge in learning and how these influence teaching practices. International Journal of Multilingualism, 8(3), 216-234.

Doyé, P. 2005. Intercomprehension. Guide for the development of language education policies in Europe: from linguistic diversity to plurilingual education. Strasbourg: Council of Europe.

Egaña, E. A., Cenoz, J., \& Gorter, D. (2015). Teachers' beliefs in multilingual education in the Basque country and in Friesland. Journal of Immersion and Content-Based Language Education, 3(2), 169-193.

European Commission/EACEA/Eurydice (2017). Key Data on Teaching Languages at School in Europe. Eurydice Report. Luxembourg: Publications Office of the European Union.

García, 0. (Ed.). (2009). Bilingual education in the 21st century: A global perspective. Chichester, UK: Wiley-Blackwell.

García, O. (2014). Multilingualism and language education. In C. Leung \& B. V. Street (Eds.), The Routledge Companion to English Studies (pp. 84-99). New York: Routledge.

García, O., \& Li Wei. (2015). Translanguaging, bilingualism and bilingual education. In W. Wright, S. Boun, \& O. García (Eds.), Handbook of Bilingual Education (pp. 223-240). Malden, MA: John Wiley.

Gorter, D. (ed). (2006). Linguistic Landscape: A New Approach to Multilingualism. Clevedon: Multilingual Matters.

Griva, E., \& Chostelidou, D. (2012). Multilingual competence development in the Greek educational system: FL teachers' beliefs and attitudes. International journal of multilingualism, 9(3), 257-271.

Haukås, Å. (2016). Teachers' beliefs about multilingualism and a multilingual pedagogical approach. International Journal of Multilingualism, 13(1), 1-18.

Hélot, C. (2008). Awareness raising and multilingualism in primary education. In J. Cenoz \& N. H. Hornberger (eds.), Encyclopedia of language and education: Knowledge about Language (2nd ed., Vol. 6), (pp.1-14). Springer US.

Hélot, C. (2011). Children's literature in the multilingual classroom: Developing multilingual literacy acquisition. In C. Hélot \& M. Ó Laoire (eds.), Language Policy for the Multilingual Classroom - Pedagogy of the Possible (pp. 42-64). Bristol, UK: Multilingual Matters. 
Hélot, C., \& Ó Laoire, M. (Eds.). (2011). Language Policy for the Multilingual Classroom Pedagogy of the Possible. Bristol, UK: Multilingual Matters.

Herdina, P., \& Jessner, U. (2002). A dynamic model of multilingualism: Perspectives of change in psycholinguistics. Clevedon: Multilingual Matters.

Heyder, K., \& Schädlich, B. (2014). Mehrsprachigkeit und Mehrkulturalität-eine Umfrage unter Fremdsprachenlehrkräften in Niedersachsen. Zeitschrift für interkulturellen Fremdsprachenunterricht, 19(1).

Horner, K., \& Weber, J. J. (2017). Flexible vs. fixed multilingualism. In Introducing multilingualism: A social approach. (pp. 139-157). London, UK: Routledge.

Hufeisen, B., \& Neuner, G. (2004). The plurilingualism project: tertiary language learning: German after English. Council of Europe.

Jessner, U. (2006). Linguistic awareness in multilinguals: English as a third language. Edinburgh: Edinburgh University Press.

Jessner, U. (2008). Teaching third languages: Findings, trends and challenges. Language teaching, 41(1), 15-56.

Jessner, U., Allgäuer-Hackl, E., \& Hofer, B. (2016). Emerging multilingual awareness in educational contexts: From theory to practice. Canadian Modern Language Review, 72(2), 157-182.

Leonet, 0., Cenoz, J., \& Gorter, D. (2017). Challenging minority language isolation: Translanguaging in a trilingual school in the Basque Country. Journal of Language, Identity \& Education, 16(4), 216-227.

Letica Krevelj, S. (2019). Strani jezik i višejezičnost: stvarnost, spoznaje i preporuke. In Y. Vrhovac et al. (Eds.) Izazovi učenja stranoga jezika u osnovnoj školi (pp. 26-34). Zagreb: Naklada Ljevak

Otwinowska, A. (2014). Does multilingualism influence plurilingual awareness of Polish teachers of English? International Journal of Multilingualism, 11(1), 97-119.

Petravić, A. (2015). Mehrsprachigkeit als Bildungsziel: Fragen der Curriculum-entwicklung aus fremdsprachendidaktischer Perspektive. In Cergol Kovačević, K., Udier, S. L. (Eds.) Multidisciplinary Approaches to Multilingualism: Proceedings from the CALS conference (2014), (199 - 226), Frankfurt am Main: Peter Lang.

Portolés, L., \& Martí, O. (2018). Teachers' beliefs about multilingual pedagogies and the role of initial training. International Journal of Multilingualism, 1-17.

Ringbom, H. (2007). Cross-linguistic Similarity in Foreign Language Learning. Clevedon: Multilingual Matters.

Sierens, S., C. Frijns, K. Van Gorp, L. Sercu and P. Van Avermaet. 2018. The effects of raising language awareness in mainstream and language classrooms: a literature review (1995-2013). In C. Hélot, C. Frijns, K. Van Gorp and S. Sierens (Eds.), Language Awareness in Multilingual Classrooms in Europe: From Theory to Practice, 21-85. Boston/Berlin: Mouton de Gruyter. 
Torres, L. (2012) Subway Sparrow. New York, NY: Farrar, Straus, Giroux, Square Fish.

Vilke, M. (2019). Djeca i učenje stranih jezika u našim školama. In Y. Vrhovac et al. (Eds.) Izazovi učenja stranoga jezika u osnovnoj školi (pp. 14-25). Zagreb: Naklada Ljevak

${ }^{1}$ We would like to thank L. Torres for giving us the permission to use the picture book for educational and research purposes and to all the teachers who dedicated their time and participated in the study. 